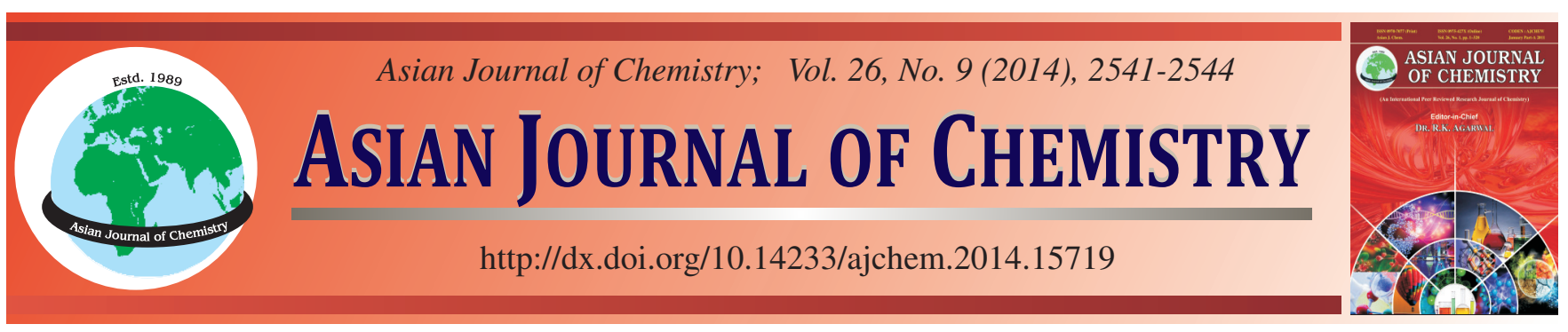

\title{
SPME/GC-MS Analysis of Volatile Organic Compounds from three Lamiaceae Species (Nepeta conferta Hedge \& Lamond, Origanum onites L. and Satureja cuneifolia Ten.) Growing in Turkey
}

\author{
Busra Yayli ${ }^{1}$, Gonca Tosun ${ }^{1}$, Mustafa Karaköse ${ }^{2}$, Gülin Renda ${ }^{3}$ and Nurettin Yayli ${ }^{3}{ }^{* *}$
}

${ }^{1}$ Department of Chemistry, Karadeniz Technical University, 61080 Trabzon, Turkey
${ }^{2}$ Faculty of Forestry, Karadeniz Technical University, 61080 Trabzon, Turkey
${ }^{3}$ Faculty of Pharmacy, Karadeniz Technical University, 61080 Trabzon, Turkey
${ }^{*}$ Corresponding author: Fax: +92 4623256717 ; Tel: +92 4623778801 ; E-mail: yayli@ktu.edu.tr

Received: 2 May 2013;

Accepted: 21 September 2013;

Published online: 28 April 2014;

AJC-15064

Solid phase microextraction of Nepeta conferta Hedge \& Lamond, Origanum onites L. and Satureja cuneifolia Ten., three Lamiaceae species to Turkey, were analyzed by GC-FID/MS. The main components of the volatile organic components were: $p$-cymene (25.5 \%), eucalyptol (9.8\%), limonene (5.0\%), sabinene (4.8\%), carvacrol (3.7\%), E-linalool oxide (3.3\%), Z-linalool oxide (3.0 \%) in $N$. conferta; carvacrol $(47.3 \%)$, p-cymene $(15.8 \%), \gamma$-terpinene $(8.6 \%)$, myrecene $(8.6 \%)$, caryophyllene $(2.0 \%)$ in $O$. onites and carvacrol $(32.6 \%), p$-cymene $(22.2 \%)$, $\gamma$-terpinene $(15.1 \%)$, myrecene $(5.5 \%)$ and caryophyllene $(3.3 \%)$ in $S$. cuneifolia. Carvacrol was the most abundant component in volatile organic compounds of $O$. onites $(47.3 \%)$, S. cuneifolia $(32.6 \%)$ and $N$. conferta $(3.7 \%)$.

Keywords: Volatile organic compounds, Nepeta conferta, Origanum onites, Satureja cuneifolia.

\section{INTRODUCTION}

The Lamiaceae family consists of more than 236 genus and 7173 species $^{1}$. They are known for the wealth of species with medicinal properties, which have been used since early times and many of these species are common in Mediterranean area and Asia $^{2}$.

The genus Nepeta L. (Lamiaceae) comprises nearly 300 species that are distributed all over the world ${ }^{3}$. The genus Nepeta L. is represented in Turkey by 39 species including 18 endemic plants ${ }^{4}$. Nepeta conferta is endemic to Turkey and it is assessed as CR (Critically endangered) in the Red Data Book of Turkish plant ${ }^{5}$. The genus Origanum L. (Lamiaceae) represented 41 species that are mainly distributed thoroughly Mediterranean basin especially East Mediterranean region ${ }^{6}$. In the literature, essential oil analysis of $N$. conferta, which was obtained by steam distillation were mentioned ${ }^{6,7}$.

The genus Origanum L. is represented in Turkey by 30 taxa and 15 of them are endemic to Turkey ${ }^{8}$, endemism rate of Origanum genus in Turkey is $50 \%$ and 5 taxa are hybrid ${ }^{4}$. Origanum onites is a non-endemic plant and naturally grows west of Turkey at Aegean and Mediterranean region ${ }^{9}$. Literature data of $O$. onites showed the chemical components of the essential oil which were obtained by steam distillation ${ }^{10-12}$.

The genus Satureja L. (Lamiaceae) consists of 284 aromatic species and widely distributed in Mediterranean basin, Asia and boreal America ${ }^{13-14}$. The genus Satureja is represented by 15 taxa in Turkey ${ }^{4}$ and 5 of them are endemic and endemism rate of Satureja genus is $33 \%$. Satureja species including Satureja cuneifolia mostly grows in the south and west Anatolia regions in Turkey ${ }^{15-16}$. In the literature, steam distillated essential oil analyses of $S$. cuneifolia were reported ${ }^{17-20}$.

The Lamiaceae family has known to be rich in volatile organic compounds. The aim of this study was to determine semi quantitative differences in volatile organic compounds of three Lamiaceae species ( $N$. conferta, O. onites and $S$. cuneifolia) by using SPME-GC-FID/MS analysis. Solid phase microextraction is an alternative technique for the extraction of organic volatiles from different sample sources, compared with conventional methods ${ }^{21-22}$. Solid phase microextraction ${ }^{23}$ represents a reliable method for the analyzing very complex mixtures of volatile organic compounds. This is the first detailed report on the volatile organic compound composition for the $N$. conferta, O. onites and S. cuneifolia based on SPME and capillary GC-FID/MS analyses.

\section{EXPERIMENTAL}

Nepeta conferta, Origanum onites and Satureja cuneifolia were collected in Antalya-Finike, Turkey, (at heights of 1370 m; Üçkuzuluk region, 530 m; Asarönü village and 2010 m; Eren mountain, respectively), southeastern part of Turkey in 3 August, 26 June and 2 August, 2012, respectively. The plants 
were authenticated by Prof.Dr.Salih Terzioglu 1,5,8,9,13,14 $^{\text {. Voucher }}$ specimens were deposited in the Herbarium of the Faculty of Forestry (KATO: 8728, KATO: 8754 and KATO: 8761, respectively), Karadeniz Technical University, Turkey.

Solid-phase microextraction/Gas chromatographymass spectrometry (SPME-GC-MS): A manual SPME device including the fiber was obtained from Supelco company (USA). The fiber used for the extraction of the volatile components was polydimethylsiloxane/divinyl-benzene (PDMS/DVB, 65 $\mu \mathrm{m}$-blue hub plain). The SPME fibers were conditioned for $5 \mathrm{~min}$ at $250{ }^{\circ} \mathrm{C}$ in the $\mathrm{GC}$ injector. For the following analyses, 4 min of desorption after each extraction was used as conditioning time. Extractions were done at $50{ }^{\circ} \mathrm{C}$ with incubation time of $5 \mathrm{~min}$ and extraction time of $10 \mathrm{~min}$. Each sample was analyzed and mean reported. For SPME procedure, about $1 \mathrm{~g}$ of the tree plant was transferred to a $10 \mathrm{~mL}$ vial. The fiber coating was placed to the head space for temperature and times (incubation and extraction times) values set according to the experiment. Extractions were achieved with shaking.

The fiber containing the extracted aroma compounds were then injected into the GC injector (split mode) and kept during 4 min for thermal desorption at $250^{\circ} \mathrm{C}$. GC analysis was carried out using a Shimadzu 2010 Plus gas chromatograph coupled to a Shimadzu QP2010 Ultra mass selective detector. The separation was performed by means of a Restek Rxi-5MS capillary column, $60 \mathrm{~m}$ length, $0.25 \mathrm{~mm}$ i.d. and a $0.25 \mu \mathrm{m}$ phase thickness. The split mode was used. The oven program was as follows: Initial temperature was $60^{\circ} \mathrm{C}$ for $2 \mathrm{~min}$, which was increased to $240{ }^{\circ} \mathrm{C}$ at $3{ }^{\circ} \mathrm{C} \mathrm{min}^{-1}, 250{ }^{\circ} \mathrm{C}$ was maintained for 4 min. Helium (99.999\%) was used as carrier gas with a constant flow-rate of $1 \mathrm{~mL} \mathrm{~min}{ }^{-1}$. Detection was carried out in electronic impact mode (EI); ionization voltage was fixed to $70 \mathrm{eV}$. Scan mode $(40-450 \mathrm{~m} / \mathrm{z})$ was used for mass acquisition. The volatile compounds were identified by comparison of their retention indices (relative to C7-C30 alkane standards) and by comparison with the mass spectra of the two libraries (FFNSC1.2 and W9N11).

\section{RESULTS AND DISCUSSION}

Three species (N. conferta, O. onites and S. cuneifolia) of the Lamiaceae family were collected in the different localities of the northwest part of Turkey. The volatile organic compounds were obtained by SPME method ${ }^{21-22}$, analyzed with GCFID-MS and identified by comparing their GC Kovats retention indexes (RI), determined with reference to a homologous series of $n$-alkanes and by comparing their mass spectral fragmentation patterns with literature data ${ }^{24-33}$. The principal components ratios of volatile organic compounds have shown a wide diversity within each species and variety of Lamiaceae family. The compositions and relative percentages of the volatile organic compounds from $N$. conferta, $O$. onites and $S$. cuneifolia were listed in table. Volatile organic compounds of $N$. conferta, $O$. onites and $S$. cuneifolia revealed 38,29 and 31 compounds and the major fractions were monoterpene compounds 43.1 , 39.6 and $53.9 \%$, respectively (Table). Nepeta volatile organic compounds were characterized by the presence of $p$-cymene $(25.5 \%)$, eucalyptol $(9.8 \%)$, limonene $(5.0 \%)$, sabinene (4.8\%), carvacrol (3.7\%), E-linalool oxide (3.3\%), Z-linalool oxide $(3.0 \%)$, which composed $77.5 \%$ of the total volatile.
In origanum volatile the most abundant compounds were also carvacrol $(47.3 \%), p$-cymene $(15.8 \%), \gamma$-terpinene $(8.6 \%)$, myrecene $(8.6 \%)$, caryophyllene $(2.0 \%)$, which participated in the mixture at $97.6 \%$. Along with carvacrol $(32.6 \%), p$ cymene $(22.2 \%), \gamma$-terpinene $(15.1 \%)$, myrecene $(5.5 \%)$ and caryophyllene $(3.3 \%)$ constituted $98.2 \%$ of Satureja volatile organic compounds. Carvacrol was the most abundant component in volatile organic compound of O. onites $(47.3 \%)$ and S. cuneifolia (32.6\%). In the volatile organic compound of $N$. conferta, $O$. onites and $S$. cuneifolia, $p$-cymene (25.5, 15.8 and $22.2 \%$, respectivelly) was found to be the major constituents. $\alpha$-Thujene, $\alpha$-pinene, $\beta$-pinene, myrecene, $\alpha$ phellandrene, $\alpha$-terpinene, $p$-cymene, E-sabinene hydrate, 4 terpineol, $\alpha$-terpineol, carvacrol, caryophyllene and $\beta$-bisabolene were the command compounds in all three Lamiaceae families ( $N$. conferta, O. onites and $S$. cuneifolia).

The Nepetoideae comprise the majority of the essential oil rich genera of the Lamiaceae and particularly tend to accumulate monoterpenoid-rich essential oils as in our case $\mathrm{e}^{25}$. Literature search revealed that caryophyllene oxide (16\%) and linalool $11.4 \%$ were the major compounds of the essential oil of $N$. conferta ${ }^{6-7}$. In our case, linalool $(0.2 \%)$ and caryophyllene oxide (\% 2.0) were the minor components of the volatile organic compound of $N$. conferta.

High amounts of carvacrol (78.3-79.5\%) and thymol $(11.6 \%)$ have been reported from Origanum majorana from Turkey and Cuba, respectively ${ }^{26,27}$. In the literature, carvacrol (62-64\%) was found to be major compound in the essential oil of $O$. onites $^{10-12}$. Linalool $(13.4 \%)$ was the second major components of the essential oil of $O$. onites ${ }^{10}$. But, in our case, we did not observed linalool using SPME-GC/MS analysis of $O$. onites. Generally, the Origanum species is characterized by the presence of two major groups; the aromatic monoterpenes ( $p$-cymene, carvacrol and thymol) and the thujanes (sabinene, sabinene hydrate and their derivatives) ) $^{28-32}$ which we observed similar result in our case for the volatile organic compounds of it.

The main constituents of Satureja montana were carvacrol $(50.2 \%)$ thymol (11\%), $\gamma$-terpinene $(5.8 \%)$, carvacrol methyl ether $(4.6 \%)$ and $p$-cymene $(4.8 \%)^{33}$. But, we did not observed thymol and carvacrol methyl ether in S. cuneifolia. Literature search revealed that carvacrol (45-59\%) was the major compound of the essential oil of $S$. cuneifolia ${ }^{17-20}$. But, seasonal variation study of the essential oil of $S$. cuneifolia showed that linalool (17-19\%) was the main compound and there was no carvacrol in the essential oil of $S$. cuneifolia ${ }^{19}$.

In our results, we generally observed similar monoterpene compounds with different ratios. But, thymol was not determined in volatile organic compounds of $N$. conferta, $O$. onites and S. cuneifolia. A comparison with literature data on the chemical composition of volatile organic compound is difficult because of the great variability of the volatile compositions, which depends on several parameters such as locality, the climatic conditions, season, extraction technique and analytical methods ${ }^{34-35}$.

\section{ACKNOWLEDGEMENTS}

This study was supported by a grant from Karadeniz Technical University, Turkey (KTU-BAP 1206). 


\begin{tabular}{|c|c|c|c|c|c|c|}
\hline \multicolumn{7}{|c|}{$\begin{array}{l}\text { TABLE } \\
\text { VOLATILE ORGANIC COMPOUNDS FROM THREE LAMIACEAE SPECIES } \\
\text { (A: Nepeta conferta, B: Origanum onites AND C: Satureja cuneifolia) }\end{array}$} \\
\hline No & Compounds & $\mathrm{A}(\%)^{\mathrm{a}}$ & $\mathrm{B}(\%)^{\mathrm{a}}$ & $\mathrm{C}(\%)^{\mathrm{a}}$ & RT & $\mathrm{RI}^{\mathrm{b}}$ \\
\hline 1 & $\alpha$-Thujene & 1.7 & 1.0 & 0.5 & 13.12 & 938 \\
\hline 2 & $\alpha$-Pinene & 2.0 & 0.6 & 0.4 & 13.46 & 946 \\
\hline 3 & 2,4(10)-Thujadien & 0.1 & - & - & 13.83 & 956 \\
\hline 4 & Camphene & - & 0.3 & 0.2 & 14.09 & 962 \\
\hline 5 & Verbenene & 0.3 & - & - & 14.28 & 966 \\
\hline 6 & Sabinene & 4.8 & - & - & 15.00 & 984 \\
\hline 7 & 1-Octen-3-ol & - & - & 0.7 & 15.00 & 984 \\
\hline 8 & $\beta$-Pinene & 1.2 & 0.1 & 0.2 & 15.22 & 989 \\
\hline 9 & 3-Octanone & 0.1 & - & - & 15.35 & 993 \\
\hline 10 & Myrecene & 0.1 & 8.6 & 5.5 & 15.54 & 998 \\
\hline 11 & Octanol & - & - & 0.9 & 15.66 & 1000 \\
\hline 12 & 3-Octanol & 0.2 & - & - & 15.69 & 1001 \\
\hline 13 & $\alpha$-Phellandrene & 0.3 & 0.4 & 0.3 & 16.25 & 1014 \\
\hline 14 & $\delta$-3-Carene & - & 0.1 & 0.1 & 16.52 & 1020 \\
\hline 15 & $\alpha$-Terpinene & 0.4 & 1.4 & 1.8 & 16.76 & 1026 \\
\hline 16 & $p$-Cymene & 25.5 & 15.8 & 22.2 & 17.09 & 1033 \\
\hline 17 & Limonene & 5.0 & 1.8 & 1.6 & 17.27 & 1038 \\
\hline 18 & $\beta$-Phallandrene & - & 0.2 & - & 17.40 & 1439 \\
\hline 19 & Eucalyptol & 9.8 & - & - & 17.44 & 1041 \\
\hline 20 & $E$ - $\beta$-Ocimene & - & 0.2 & 5.3 & 17.47 & 1042 \\
\hline 21 & $\gamma$-Terpinene & 0.9 & 8.6 & 15.1 & 18.54 & 1067 \\
\hline 22 & E-Sabinene hydrate & 1.5 & 1.3 & 0.6 & 18.92 & 1076 \\
\hline 23 & $E$-Linalool oxide & 3.3 & - & - & 19.11 & 1080 \\
\hline 24 & 1-Nonen-3-ol & - & - & 0.1 & 19.24 & 1083 \\
\hline 25 & Z-Linalool oxide & 3.0 & - & - & 19.79 & 1096 \\
\hline 26 & Terpinolene & - & 0.4 & 0.4 & 19.84 & 1097 \\
\hline 27 & Linalool & 2.0 & - & 0.5 & 20.15 & 1104 \\
\hline 28 & 3-Tridecene & 0.1 & - & - & 20.75 & 1118 \\
\hline 29 & $\alpha$-Thujone & 0.8 & - & - & 21.10 & 1126 \\
\hline 30 & Neo-allo-Ocimene & - & - & 0.3 & 21.44 & 1134 \\
\hline 31 & $\alpha$-Campholenal & 0.6 & 0.2 & - & 21.50 & 1135 \\
\hline 32 & Phellandral & 0.1 & - & - & 21.61 & 1138 \\
\hline 33 & E-Pinocarveol & 2.2 & - & - & 22.12 & 1150 \\
\hline 34 & Verbenol & 0.6 & - & - & 22.33 & 1154 \\
\hline 35 & Pinocarvone & 1.0 & - & - & 23.18 & 1165 \\
\hline 36 & Endo-Borneol & - & 2.0 & 1.6 & 23.29 & 1177 \\
\hline 37 & Phallandrol & - & 0.3 & - & 23.46 & 1180 \\
\hline 38 & 4-Terpineol & 2.2 & 0.9 & 0.8 & 23.74 & 1187 \\
\hline 39 & $\alpha$-Terpineol & 0.2 & 0.1 & 0.2 & 24.27 & 1199 \\
\hline 40 & Z-Dihydrocarvone & - & 0.1 & 0.3 & 24.58 & 1207 \\
\hline 41 & (R)-(-)-Myrtenal & 1.0 & - & - & 24.63 & 1208 \\
\hline 42 & $E$-Dihydrocarvone & - & 0.1 & 0.1 & 24.93 & 1215 \\
\hline 43 & Verbenone & 0.7 & & - & 25.18 & 1221 \\
\hline 44 & $E$-Carveol & 0.1 & & - & 25.44 & 1227 \\
\hline 45 & Cuminaldehyde & 0.5 & & - & 26.41 & 1250 \\
\hline 46 & (-)-Carvone & - & 0.2 & - & 26.58 & 1254 \\
\hline 47 & Thymoquinone & - & - & 1.2 & 26.75 & 1258 \\
\hline 48 & Linalyl acetate & - & 1.8 & - & 26.77 & 1259 \\
\hline 49 & Carvacrol & 3.7 & 47.3 & 32.6 & 28.75 & 1306 \\
\hline 50 & $\alpha$-Copaene & 0.9 & - & - & 32.04 & 1388 \\
\hline 51 & Tetradecane & 0.1 & - & - & 32.51 & 1400 \\
\hline 52 & Caryophyllene & 0.1 & 2.0 & 3.3 & 33.84 & 1435 \\
\hline 53 & $\alpha$-E-Bergamotene & - & 0.1 & - & 34.24 & 1445 \\
\hline 54 & Aromadendrene & - & 0.3 & 0.2 & 34.59 & 1455 \\
\hline 55 & $\alpha$-Humulene & - & - & 0.1 & 35.16 & 1469 \\
\hline 56 & $\beta$-Bisabolene & 0.2 & 1.4 & 1.0 & 36.95 & 1517 \\
\hline
\end{tabular}




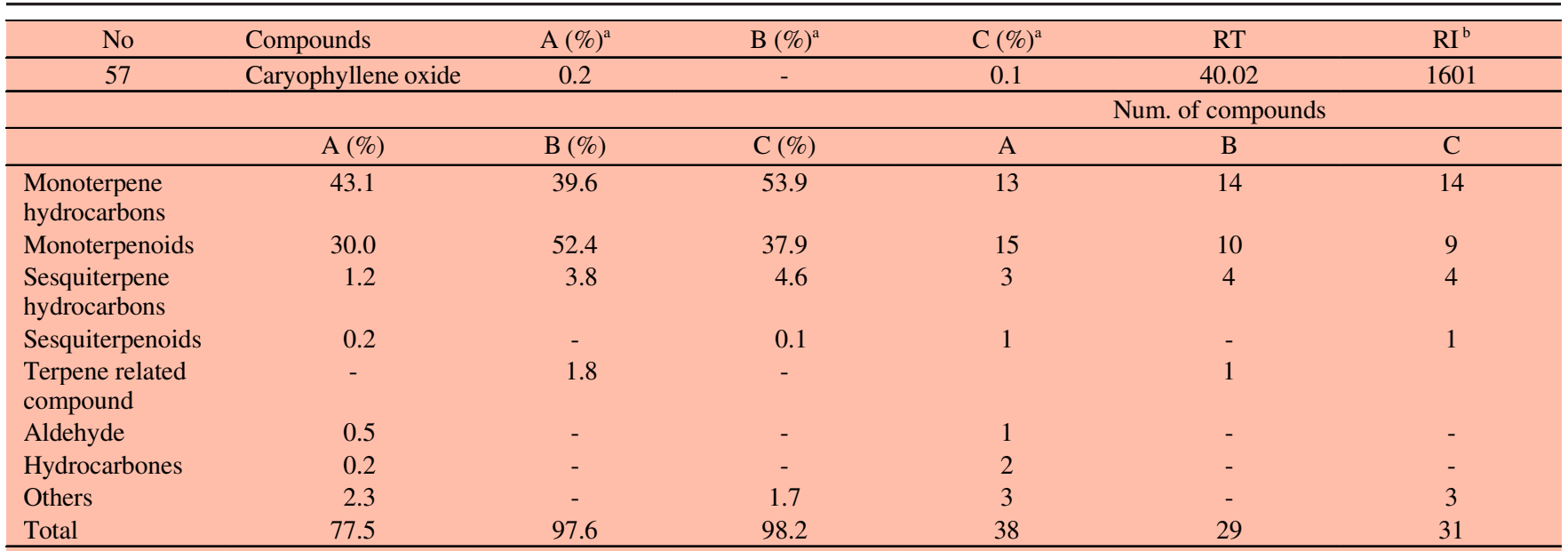

${ }^{\text {a }} \%$ Area obtained by FID peak-area normalization. ${ }^{\text {b }}$ I calculated from retention times relative to that of $n$-alkanes $\left(\mathrm{C}_{7}-\mathrm{C}_{30}\right)$ on the non-polar HP-5 column

\section{REFERENCES}

1. I.C. Hedge and J.M. Lamond, ed: P.H. Davis, Nepeta L.; In: Flora of Turkey and East Aegean Islands, Edinburgh University Press, Edinburgh, Vol. 7, pp. 264-288 (1982).

2. R.M. Harley, S. Atkins, A.L. Budantsev, P.D. Cantino, B.J. Conn, R. Grayer, M.M. Harley, R. De Kok, T. Krestovskaja, R. Morales, A.J. Paton, O. Ryding and T. Upson, ed.: K. Kubitzki, The Families and Genera of Flowering Plants, Springer-Verlag, Berlin, Vol. 7, pp. 167-275 (2004).

3. A. Kaya and T. Dirmenci, Turk. J. Bot., 32, 103 (2008).

4. A. Güner, S. Aslan, T. Ekim, M. Vural and M.T. Babaç, Türkiye'nin Bitkileri Listesi (Damarli Bitkiler), NGBB ve Flora Aras. Der. Yayini, Syf 1290, Istanbul (2012).

5. T. Ekim, M. Koyuncu, M. Vural, H. Duman, Z. Aytaç and N. Adigüzel, Red Data Book of Turkish Plants, Pteridophyta and Spermatophyta, Bariscan Ofset, Ankara, p. 246 (2000).

6. T. Özek, N. Tabanca, F. Emirci, E.E. Wedge and K.H.C. Baser, Rec. Nat. Prod., 4, 180 (2010).

7. K.H.C. Baser, N. Kirimer, M. Kurkcuoglu and B. Demirci, Chem. Nat. Compd., 36, 356 (2000).

8. J.H. Ietswaart, A Taxonomic Revision of the Genus Origanum, Leiden University Press, London (1980).

9. J.H. Ietswaart, in ed.: P.H. Davis, Origanum L. In: Flora of Turkey and East Aegean Islands, Edinburgh University Press, Edinburgh, Vol. 7, pp. 297-313 (1982).

10. S. Coskun, O. Girisgin, M. Kürkcüoglu, H. Malyer, A.O. Girisgin, N. Kirimer and K.H.C. Baser, Parasitol. Res., 103, 259 (2008).

11. O. Toncer, S. Karaman, S. Kizil and E. Diraz, Notulae Botanicae Horti Agrobotanici Cluj-Napoca, 37, 177 (2009).

12. G. Ruberto, D. Biondi, R. Meli and M. Piattelli, Flav. Fragr. J., 8, 197 (1993).

13. A. Rustaiyan, A. Feizbakhsh, S. Masoudi and N. Ameri, J. Essent. Oil Res., 16, 594 (2004).

14. M. Kameli, S.M.H. Hejazi and M. Ebadi, Annals Biol. Res., 4, 64 (2013).

15. P.H. Davis, Satureja L. In: Flora of Turkey and East Aegean Islands, Edinburgh: Edinburgh University Press, Vol. 7, pp. 314-323 (1982).

16. A. Kaya, F. Satil and F. Gogel, Biologia, 64, 902 (2009).

17. F. Oke, B. Aslim, S. Öztürk and S. Altundag, Food Chem., 112, 874
(2009).

18. B. Biavati, Ann. Microbiol., 54, 393 (2004).

19. S. Mirjana, B. Nada and D. Valerija, Eur. Food Res. Technol., 218, 367 (2004).

20. Y. Kan, U.S. Uçan, M. Kartal, M.L. Altun, S. Aslan, E. Sayar and T. Ceyhan, Turk. J. Chem., 30, 253 (2006).

21. J. Pawliszyn, Handbook of Solid Phase Microextraction, Chemical Industry Press (2009).

22. J. Pawliszyn, Applications of Solid Phase Microextraction, Royal Society of Chemistry (1999).

23. C. Arthur and J. Pawliszyn, Anal. Chem., 62, 2145 (1990).

24. R.P. Adams, Identification of Essential Oil Components by Gas Chromatography-Mass Spectroscopy, Allured, Carol Stream, IL, USA (2004).

25. C. Formisano, D. Rigano and F. Senatore, Chem. Biodivers., 8, 1783 (2011).

26. K.H.C. Baser, N. Kirimer and G. Tümen, J. Essent. Oil Res., 5, 577 (1993).

27. J. Pino, A. Rosado, M. Estarron and V. Fuentes, J. Essent. Oil Res., 9, 479 (1997).

28. M. Skoula, P. Gotsiou, G. Naxakis and C.B. Johnson, Phytochemistry, 52, 649 (1999).

29. B. Bellomaria, G. Valentini and E. Biondi, J. Essent. Oil Res., 5, 391 (1993).

30. M. Charai, M. Mosaddak and M. Faid, J. Essent. Oil Res., 8, 657 (1996).

31. M. Komaitis, N. Ifanti-Papatragianni and E. Melissari-Panagiotou, Food Chem., 45, 117 (1992).

32. M. Russo, G. Galletti, P. Bocchini and A. Carnacini, J. Agric. Food Chem., 46, 3741 (1998).

33. M. Skocibusic and N. Bezic, Pharm. Biol., 41, 622 (2003).

34. G. Flamini, P.L. Cioni, and I. Morelli, J. Chromatogr. A, 998, 229 (2003).

35. S. Vichi, A.I. Castellote, L. Pizzale, L.S. Conte, S. Buxaderas and E. Lo'pez-Tamames, J. Chromatogr. A, 983, 19 (2003). 